\title{
Effect of some insecticides alone and in combination with salicylic acid against aphid, Aphis gossypii, and whitefly Bemisia tabaci on the cotton field
}

\author{
Abd El-Hakeem El-Dmerdash El-Sherbeni ${ }^{1}$, Mohamed Sengab Khaleid ${ }^{2}$, Sabry Abd El All AbdAllah ${ }^{1 *}$ (D) and
} Ola Saber Mohammed Ali $^{2}$

\begin{abstract}
Background: Cotton is one of the most important industrial crops in Egypt and worldwide. During its growth stages, cotton is threatened by several pests including aphids (Aphis gossypii Glover) and whiteflies (Bemisia tabaci) which lead to deleterious effects on cotton growth, yield, and quality. Due to health and environmental hazards of pesticides, it is important to reduce them by using eco-friendly alternatives. Two field experiments were carried out to investigate the effect of some insecticides including profenofos (Prf), cyhalothrin (Cyh), and imidacloprid (Imd) individually or in combination with salicylic acid (SA) against cotton aphids and whiteflies.

Results: All spray treatments had potent and moderated effects against aphids and whiteflies, respectively. The Prf insecticide at $100 \%$ of the recommended dose was the most effective one against both pests followed by the Cyh. The insecticidal effect of SA against the tested pests was concentration dependent. The most effective combination treatments were Prf at 75\% of recommended dose + SA at a concentration of $1 \mathrm{mM}$ for aphids (reduction \% 95.68), and Cyh at $75 \%$ of recommended dose + SA $(0.5 \mathrm{mM})$ for whiteflies (reduction of $88.00 \%)$. All tested insecticides, individually or in combination with SA, significantly increased total phenolic (TP) content in treated plants compared with control. The maximum increase in TP content was recorded in cotton plants treated with Prf in combination with SA.
\end{abstract}

Conclusions: Salicylic acid enhanced the effectiveness of the used insecticides, and thus, SA could be used to lower the amount of insecticides with increasing insecticidal efficacy.

Keywords: Salicylic acid, Cotton, Aphis gossypii, Bemisia tabaci, Profenofos, Cyhalothrin, Imidacloprid

\section{Introduction}

Cotton is one of the most important cash crops that plays a key role in the Egyptian agricultural economy. Cotton is attacked by many insects and pathogens from the seedling stage to the fruiting stage. With the increasing use of chemical pesticides, farmers have increasing problems with sucking insects. Among sucking pest, cotton aphids (Aphis gossypii Glover) and cotton whiteflies (Bemisia tabaci) are considered the most important

\footnotetext{
*Correspondence: sabry.abdelaal@agr.tanta.edu.eg

'Plant Protection Department, Faculty of Agriculture, Tanta University, Tanta, Egypt

Full list of author information is available at the end of the article
}

insect pests threatening cotton crop. These insects cause a significant yield loss due to their rapid reproduction and by sucking plants sap producing the honeydew that pollutes the opened boll lint (Schepers, 1989) and provides suitable conditions for the growth of fungi on the leaves and bolls (Ahmad et al., 2002) and transmission of viral diseases leading to a deleterious effect on seed yield and fiber quality.

Many pesticides have been used so far to control these insects, but their indiscriminate use leads to developing the ability of the pest to tolerate high concentrations of the pesticide without killing it (called resistance phenomenon). This leads to using more pesticides to get satisfactory 
control results causing an increase in environmental pollution with pesticides and disturbance of the natural ecological balance.

Systemic acquired resistance (SAR) is defined as the induced response to various biotic (feeding by insects or infections by pathogenic organisms) and abiotic or chemical elicitors (such as salicylic acid and jasmonic acid), attributed to the synthesis of defensive phytochemicals (Kogan and Paxton, 1983). However, the research in the induced resistance against insect herbivore is limited (Karban and Kuc, 1999).

The present study hypothesized that salicylic acid (SA), as an inducer for plant resistance, can be used to activate the effectiveness of insecticides against sucking pests. Therefore, this study aimed to reduce the amount of used insecticides by mixing them with SA to control sucking pests including aphids (Aphis gossypii) and whiteflies (Bemisia tabaci) in cotton plants under field conditions.

\section{Materials and methods}

The experimental trials were conducted at the farm of Ity El-Baroud Agric. Res. Station during two successive seasons (2010 and 2011), to assay the efficacy of three insecticide tanks mixed with salicylic acid against aphids, Aphis gossypii, and whiteflies Bemisia tabaci on a cotton field. All tested insecticides, in formulated forms, were obtained from the Central Laboratory of Pesticides, Agric. Res. Center, Giza, Egypt. These insecticides were Actacrone $72 \%$ E.C (profenofos), Cyhalon $2.5 \%$ E.C (cyhalothrin), and Joun 20\% WP (imidacloprid).
As described in Table 1, the trials included 16 treatments which comprised salicylic acid that was used individually at three concentrations $(0.5,0.75$, and $1.0 \mathrm{mM})$; three insecticides (profenofos, cyhalothrin, and imidacloprid) that were used individually at $100 \%$ of the recommended dose, i.e., $75,37.5$, and $15 \mathrm{ml} / 20 \mathrm{~L}$ water, in addition to 9 combinations treatments including the mixture of each insecticide at $75 \%$ of their recommended dose with SA at different concentrations; and water that was used as control treatment.

Soil texture was as clay soil with clear uniforms without notable deviations in the texture. Giza- 88 variety was used in this study. The seeds were from the Cotton Plant Research Institute, Agric. Res. Center, Giza, Egypt. The experimental design was a complete randomized block, with three replicates of each treatment. The area of the experimental plot was $42 \mathrm{~m}^{2}$ with 10 ridges. The hill plantation was made on one side of a ridge with a space $25 \mathrm{~cm}$ apart. Three seeds were sowed per hill. The plants were thinned to one plant per hill. The first spray was carried out on August 20 and the second one was conducted over 15 days using a knapsack sprayer.

After each spray, the number of aphids and whiteflies on 10 leaves was recorded for each plot. Leaf samples were taken at 24,48 , and $72 \mathrm{~h}$ for laboratory evaluation. Ten leaves for each replicate were randomly collected in a paper bag and considered as the sample representing this plot. Laboratory evaluation was achieved after sampling by using the stereoscopic binocular microscope; both surfaces of the leaflets were examined for both aphids and whitefly insects and counted. The efficiency

Table 1 Mixtures of insecticides/salicylic acid used in the field experiments and their application rates

\begin{tabular}{|c|c|c|}
\hline Treatments & Mixture (mixed tank) & Rate of application/20 LW \\
\hline Control (untreated check) & Water & $20 \mathrm{ml}$ ethyl alcohol \\
\hline Salicylic acid (SA) $0.5 \mathrm{mM}$ & Salicylic acid & $10 \mathrm{ml}(1 \mathrm{~mol})^{*}$ \\
\hline SA $0.75 \mathrm{mM}$ & Salicylic acid & $15 \mathrm{ml}(1 \mathrm{~mol})$ \\
\hline SA $1 \mathrm{mM}$ & Salicylic acid & $20 \mathrm{ml}(1 \mathrm{~mol})$ \\
\hline Imidacloprid (Imd) & Imidacloprid at $100 \%$ of the recommended rate & $15 \mathrm{ml}$ Imidacloprid \\
\hline Imd + SA $0.5 \mathrm{mM}$ & Imidacloprid at $75 \%$ of recommended rate + SA 0.5 mM & $11 \mathrm{ml}$ Imidacloprid + $10 \mathrm{ml} \mathrm{SA}(1 \mathrm{~mol})$ \\
\hline Imd + SA $0.75 \mathrm{mM}$ & Imidacloprid at $75 \%$ of recommended rate + SA 0.75 mM & $11 \mathrm{ml}$ Imidacloprid + $15 \mathrm{ml} \mathrm{SA}(1 \mathrm{~mol})$ \\
\hline Imd + SA $1 \mathrm{mM}$ & Imidacloprid at $75 \%$ of recommended rate + SA 1 mM & $11 \mathrm{ml}$ Imidacloprid + $20 \mathrm{ml} \mathrm{SA}(1 \mathrm{~mol})$ \\
\hline Cyhalothrin (Cyh) & Cyhalothrin at $100 \%$ of recommended rate & $37.5 \mathrm{ml}$ Cyhalothrin \\
\hline Cyh + SA $0.5 \mathrm{mM}$ & Cyhalothrin at $75 \%$ of recommended rate + SA $0.5 \mathrm{mM}$ & $25 \mathrm{ml}$ Cyhalothrin + $10 \mathrm{ml} \mathrm{SA}(1 \mathrm{~mol})$ \\
\hline Cyh + SA 0.75 mM & Cyhalothrin at $75 \%$ of recommended rate + SA $0.75 \mathrm{mM}$ & $25 \mathrm{ml}$ Cyhalothrin + $15 \mathrm{ml} \mathrm{SA}(1 \mathrm{~mol})$ \\
\hline Cyh + SA $1 \mathrm{mM}$ & Cyhalothrin at $75 \%$ of recommended rate + SA 1 mM & $25 \mathrm{ml}$ Cyhalothrin + $20 \mathrm{ml} \mathrm{SA}$ (1 mol) \\
\hline Profenofos (Prf) & Profenofos at $100 \%$ of the recommended rate & $75 \mathrm{ml}$ Profenofos \\
\hline Prf + SA $0.5 \mathrm{mM}$ & Profenofos at $75 \%$ of recommended rate + SA $0.5 \mathrm{mM}$ & $50 \mathrm{ml}$ Profenofos + $10 \mathrm{ml}(1 \mathrm{~mol})$ \\
\hline Prf + SA $0.75 \mathrm{mM}$ & Profenofos at $75 \%$ of recommended rate + SA 0.75 mM & $50 \mathrm{ml}$ Profenofos $+15 \mathrm{ml}(1 \mathrm{~mol})$ \\
\hline Prf + SA $1 \mathrm{mM}$ & Profenofos at $75 \%$ of recommended rate + SA $1 \mathrm{mM}$ & $50 \mathrm{ml}$ Profenofos $+20 \mathrm{ml}(1 \mathrm{~mol})$ \\
\hline
\end{tabular}

$L W$ liter water. ${ }^{*}$ The molecular weight of the salicylic acid $(138 \mathrm{~g})$ was dissolved in $1000 \mathrm{ml}$ ethyl alcohol 
of pesticides was calculated according to the following equation:

$$
\% \text { reduction }=\frac{A-B}{A} \times 100
$$

where $A=$ counts in control and $B=$ counts in treatments after insecticides and/or salicylic acid spraying.

\section{Determination of total phenolic compounds}

Total phenolic compounds were determined in the leaves of the treated and untreated plants (control). Three replicates were used for each treatment. Phenolic extractions were carried out according to a modified method of Johnson and Schaal (1957). Twenty-five milliliters of $95 \%$ ethanol was added to $2 \mathrm{~g}$ fresh weight of leave tissue of each treatment, then each sample was smashed for $3 \mathrm{~min}$ in a Waring blender (Molyneux 534 Fins - Herb electric Mill) and filtrated in a 25-ml test tube using a Whatman No. 1 filter paper. Each test was replicated three times. A half $\mathrm{ml}$ of each extract was added to $12.5 \mathrm{ml}$ of distilled water in a test tube, then $0.5 \mathrm{ml}$ Folin-Denis reagent was added to each tube, and then they took and allowed it to stand for 2-3 min; 3.5 $\mathrm{ml}$ of $10 \%$ sodium carbonate was added to each tube, then the tubes were shaken and allowed to stand again for about 90 min until a blue color forms in the tubes containing all reagents without the plant extracts prepared at the same time to serve as a control treatment. The optical density of $1 \mathrm{ml}$ aliquots of each tube content was determined using a Spectronic-20 spectrophotometer at a wavelength of $660 \mathrm{~nm}$. The amounts of total phenolic compounds were calculated according to a standard curve of phenolic acid which was made at the same time of measurement and expressed as microgram $(\mu \mathrm{g})$ equivalent of phenolic acid per 1 gram fresh weight of cotton tissue samples.

\section{Statistical analysis}

All data were statistically analyzed by analysis of variance (ANOVA) using the Statistical Analysis System (SAS Institute, Inc., 1996). Means were compared by the least significant difference (LSD) test at a $P \leq 0.05$ level.

\section{Results}

\section{Effect of the insecticides and salicylic acid, alone or in} combination with SA, against cotton aphids

The population density of the cotton aphids A. gossypii in the cotton field experiments was determined during two cotton seasons of 2010 and 2011. The number of insects was counted after 24, 48, and $72 \mathrm{~h}$. The efficiency of pesticides was estimated by calculating the reduction percentage $(\mathrm{R} \%)$ of the aphid population.
Data illustrated in Fig. 1 show that all spray treatments significantly $(P \leq 0.05)$ reduced the average number of aphids. In regard to the insecticides alone, Prf was the most effective insecticide in reducing the density of the aphid population ( $\mathrm{R} \%$ was 95.39 and 86.91 for seasons 2010 and, 2011 respectively) followed by the Cyh (R\% was 88.26 and 78.17 for seasons 2010 and, 2011 respectively). The individual application of SA has a significant effect against cotton aphids and that effect was concentration dependent.

Regarding the combination treatments, SA markedly enhanced the effectiveness of all insecticides that were applied at $75 \%$ of their recommended dose. In season 2010, the most effective combination treatment was profenofos + 1.0 mM SA (R\% was 96.67). Similarly, in season 2011, the same treatment ( $\operatorname{Prf}+1.0 \mathrm{mM} \mathrm{SA})$ was the most effective one in reducing cotton aphids ( $\mathrm{R} \%$ 95.68\%).

Imidacloprid and cyhalothrin, alone or in combination with SA at different concentrations, exhibited lesser and moderate effects, respectively. Accordingly, the application of Prf, individually or in combination with SA, was the most promising insecticide to control cotton aphids (A. gossypii) during growing seasons under field conditions.

\section{Effect of the insecticides and salicylic acid, alone or in combination with SA, against the immature stage (nymphs) of whiteflies}

In both seasons, all tested insecticides, alone or in combination with SA, significantly reduced the number of whiteflies in cotton plants compared with nontreated control (Fig. 2). For the individual application of insecticides, the three tested insecticides had a moderate influence on the whiteflies. In addition, the individual application of SA at concentrations of 0.5 , 0.75 , and $1.0 \mathrm{mM}$ significantly reduced the whiteflies ( $\mathrm{R} \%$ were $32.79,40.19$, and $51.99 \%$, respectively for the 2010 season, and $18.75,22.57$, and, $33.69 \%$ respectively for the 2011 season). Thus, the efficacy of SA increased when increasing its concentration.

In case of combining the insecticides with a different rate of the SA mixed tank, SA had enhanced the effect of the three insecticides in controlling whiteflies on cotton plants. Also, the enhanced effect was dependent on the rate of application. In the case of season 2010, the most effective spray treatments were Cyh $+0.5 \mathrm{mM}$ SA followed by Prf + SA $0.75 \mathrm{mM}$ (R\% were 85.77 and 81.98 respectively). In season 2011, the most effective treatments were Prf + SA $1 \mathrm{mM}$ and Cyh + SA 0.5 mM (R\% were 90.75 and 90.32). From the average reduction percentage for the two seasons, we could conclude that the most effective treatments were Cyh + SA $0.5 \mathrm{mM}$ followed by Prf + SA $1 \mathrm{mM}$ (R\% were 88.00, 85.88, and 85.88). 

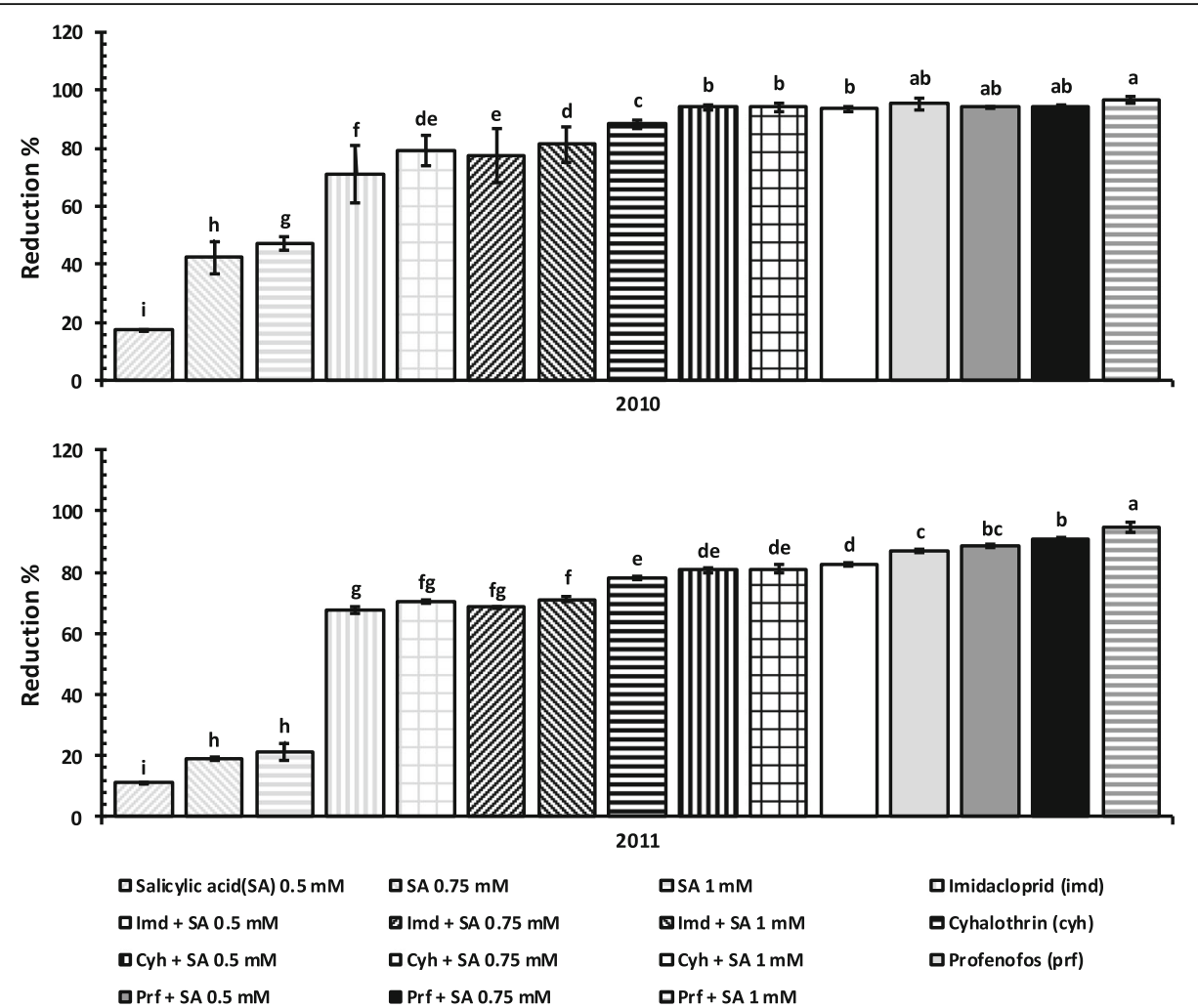

Fig. 1 Efficiency of certain insecticides and/or salicylic acid combination against the cotton aphids, Aphis gossypii, in cotton plants
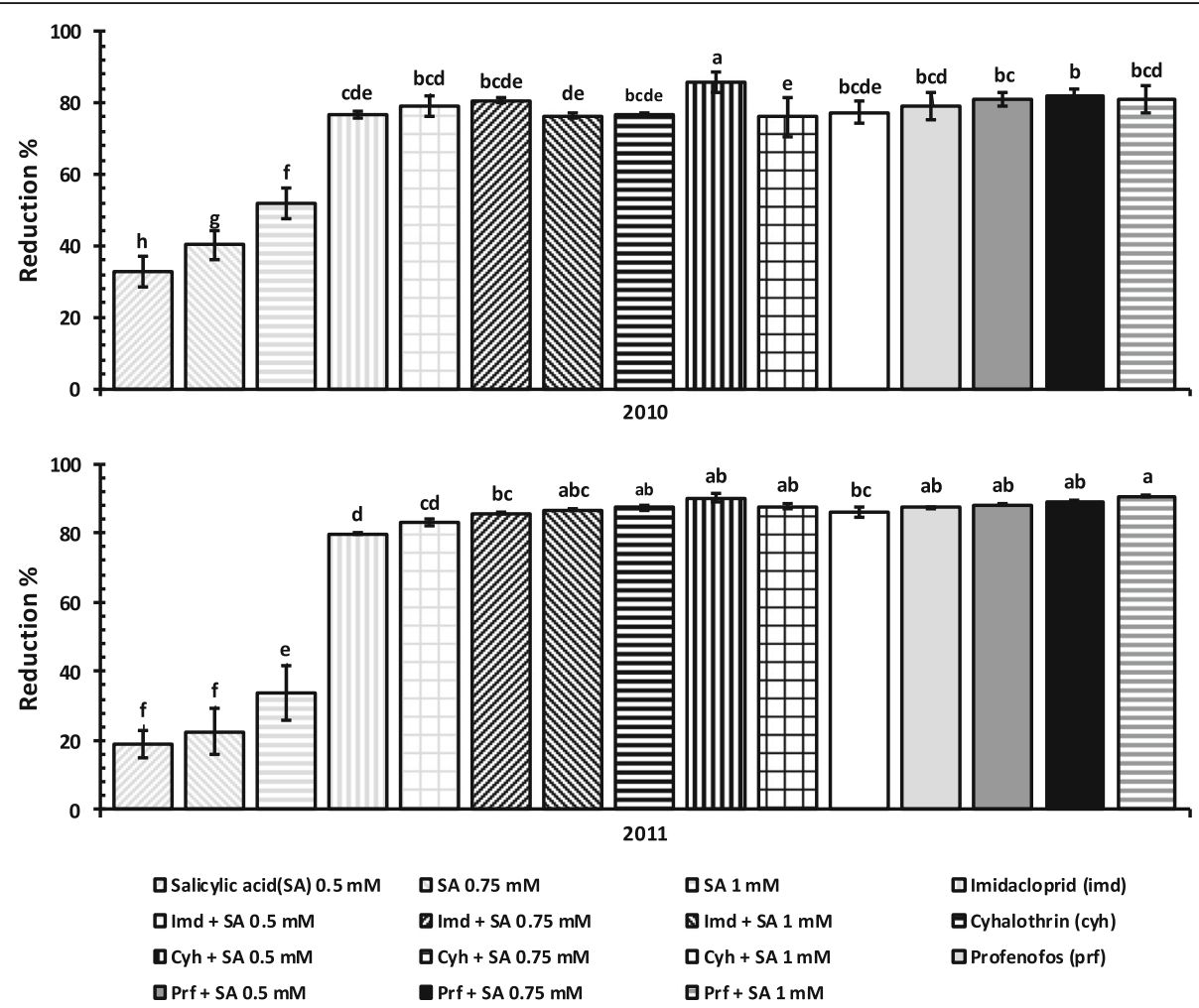

Fig. 2 Efficiency of certain insecticides and/or SA combination against the immature stage of the whiteflies $B$. tabaci in cotton plants 
Effect of the insecticides used alone and in combination with salicylic acid on total phenolic compounds

In this study, total phenolic compounds in the leaves of cotton variety Giza (88) were assessed as an indicator of the degrees of resistance or susceptibility to insects. The data taken are illustrated in Fig. 3.

These data proved that, in both seasons, all tested insecticides, alone or in combination with SA, increase the amount of total phenolic contents. The increase of total phenolic content was dependent on the SA rate of application. The most effective insecticides for increasing the total phenolic contents were profenofos followed by cyhalothrin and imidacloprid. For the combination, profenofos combined with SA gave the highest amount of total phenolic contents (\% control ranged between 112.50 and 157.89).

\section{Discussion}

Chemical management is still the most effective strategy to control pests and pathogens. The present work revealed that the recommended dose of the individual application of profenofos insecticide achieved the most efficacy against cotton aphids (Aphis gossypii), while imidacloprid and cyhalothrin had a moderate influence on the whiteflies (Bemisia tabaci). Our results are inconsistent with the findings of AbdEl-Latief and Gindy (2006) who found that the profenofos insecticide had a potent effect against $A$. gossypii under laboratory conditions. Additionally, El-Naggar and Zidan (2013) concluded that imidacloprid had a high efficacy against aphids and had a moderate effect against whiteflies on the cotton plants.

Owing to the deleterious effects of pesticides on environment and human health, it is important to reduce their used amounts, partially or totally, by natural of safe eco-friendly alternatives. One of these alternatives is salicylic acid (SA) which is used in the present study to lower the amounts of insecticides to $75 \%$ of their recommended dose. Salicylic acid is a potent plant hormone (Hayat et al., 2010) and has a significant role for alleviating the devastating effects generated by various biotic and abiotic stresses on plants (Catinot et al., 2008). Salicylic acid at a concentration of $1 \mathrm{mM}$ acted synergistically with nitric oxide and hydrogen peroxide for reducing the deleterious effects of biotic stress caused by Podosphaera xanthii in squash plants through inducing their resistance to this pathogen (Maswada et al., 2014).

Plants have developed many morphological, biochemical, and molecular mechanisms. The biochemical mechanisms are integrated into a wide network of responses to pathogens and pests that are mediated by several signaling pathways including those controlled by SA, jasmonic acid, and ethylene, as well as other signaling
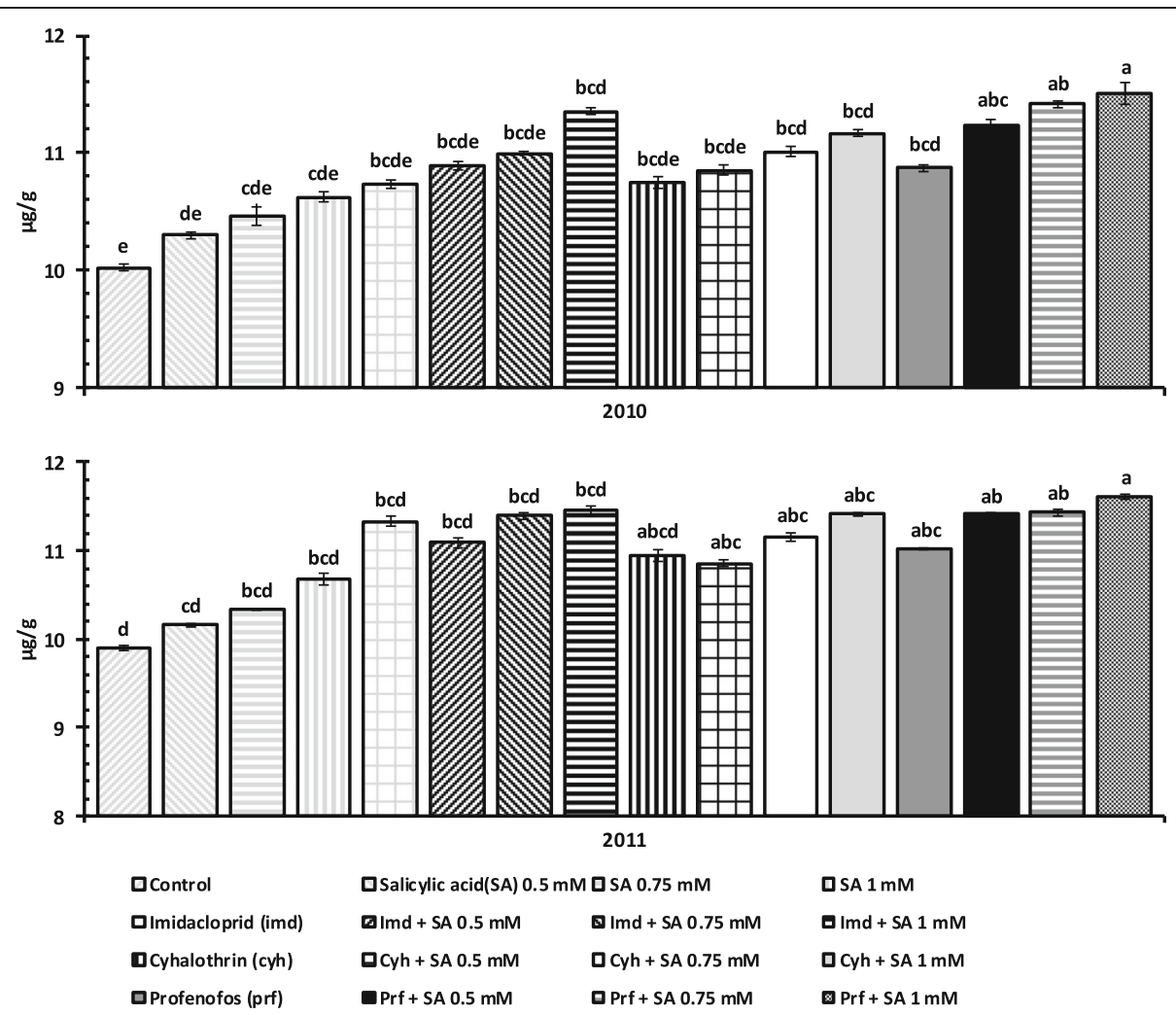

Fig. 3 Effect of certain insecticides and/or SA combination on total phenolic compounds in cotton leaves ( $\mu \mathrm{g} / \mathrm{g}$ phenolic acid) 
pathways (Robert-Seilaniantz et al., 2011). Moreover, the defensive compounds were also produced continuously or produced in response to plant damage or to the effect of feeding, growth, and survival of herbivores. Plants also release volatile compounds that attract the natural enemies of the herbivores. Those mechanisms either work independently or associated with each other.

The present work demonstrated that the individual application of SA at various concentrations $(0.5,0.75$, and $1.0 \mathrm{mM}$ ) had a slight effect in reducing the population density of aphids (Aphis gossypii) and whiteflies (Bemisia tabaci) of cotton plants, and its effect was increased when increasing its concentration. In the harmony of our results, Ali et al. (2010) stated that salicylic acid at a concentration of $0.02 \%$ was effective against $B$. tabaci under field conditions. Moreover, the treated plants with SA elicited a strong plant resistance against whiteflies and reduced its fecundity and longevity (Shi et al., 2013, and VanDoorn et al., 2015). Furthermore, Thaler et al., (2010) reported that aphid growth was superior on salicylate-lacking plants than on wild-type plants and was lower on salicylate-induced plants than on non-treated control plants.

Phenols act as a defense mechanism contrary to herbivore. Quantitative or qualitative change in the phenol amounts in the plant, as well as increased activity of phenol-oxidase enzymes, is a common phenomenon in induced resistance (War et al., 2011). Similarly, RodriguezSaona et al. (2003) stated that whiteflies can decrease the emission of volatiles by plants. Rodríguez-Álvarez et al. (2015) found that treating a tomato plant with SA led to increasing the quantities of some volatile terpenes and repelled $B$. tabaci. The release of plants for the volatile compounds is a type of indirect resistance, where it is attracting natural enemies to the site of herbivory (Rodríguez-Álvarez et al. (2015).

It is evident from the obtained results that the treated cotton plants with SA exhibited higher accumulation of phenolics in their leaves compared with untreated plants. These results are inconsistent with the results of tissue culture experiments showing that the treatment of callus led to increased cell content of the secondary metabolites, including phenols (Mahalakshmi et al., 2013; Mendhulkar and Vakil, 2013). Moreover, Villada et al., (2009) observed rapid accumulation of callose deposits, phenol, and lignin synthesis after aphid infestation on resistance melon type. In addition, our results showed that the tested insecticides significantly increased the leaf phenolic content, which may be because any change in a plant that occurs following herbivory or environmental factors is an induced response ( $\mathrm{Ti}$ and Zhang 2009). Exposure of tobacco plants Nicotiana tabacum to soil application with Bensulfuron-methyl (BSM) herbicide increased jasmonic acid (JA) and SA concentrations and increased plant resistance to whiteflies (B. tabaci) and aphids (M. persicae) with the activation of resistance genes (Li et al., 2016).

The present study declared that SA activated the activity of the tested insecticides at $75 \%$ of their recommended dose against both aphids and whiteflies on cotton plants than their activity at $100 \%$ of the recommended dose. This could be related to the increased total phenolic compounds in cotton leaves, particularly the combination of Prf with SA $(1.0 \mathrm{mM})$.

From the previous literature, SA induces plant resistance against biotrophic pathogens and some phloem-feeding insects, while JA-mediated responses are engaged against herbivores and necrotrophic pathogens (Stout et al. 1999). There is a mutually antagonistic between the two pathways (Kunkel and Brooks, 2002). In our study, adding SA was to mix it in the tank which is difficult to implement by most farmers. Therefore, we hope to study how to convert the insecticide mixtures with SA into ready-to-use formulations.

\section{Conclusion}

Adding SA to the pesticides to control aphids and whiteflies of cotton plants led to an increase in the efficiency of the process and reduction of pesticide use by $25 \%$. This is due to the increased leaf contents of phenolic compounds.

\section{Abbreviations \\ ANOVA: Analysis of variance (statically test); BSM: Bensulfuron-methyl (herbicide); Cyh: Cyhalothrin (insecticides); Imd: Imidacloprid (Insecticides); JA: Jasmonic acid (plant hormone); LSD: Least significant difference; LW: Litter water; P: Probability; Prf: Profenofos (insecticides); R\%: Reduction percentage; SA: Salicylic acid}

\section{Acknowledgements}

Not applicable

\section{Funding}

This work is part of published MSc thesis with the title "Effect of salicylic acid and its mixtures with three insecticides on some cotton insect pests" Introduced by Ola Saber Mohammed Ali.

\section{Availability of data and materials}

All data generated or analyzed during this study are included in this published article [and its supplementary information files].

\section{Authors' contributions \\ AE-EL-SH is the principal author. MSK is the co-author. SAA is the co-author and the corresponding author. OSMA is the co-author. All authors read and approved the final manuscript.}

\section{Ethics approval and consent to participate} Not applicable

\section{Consent for publication \\ Not applicable}

Competing interests

The authors declare that they have no competing interests. 


\section{Publisher's Note}

Springer Nature remains neutral with regard to jurisdictional claims in published maps and institutional affiliations.

\section{Author details}

'Plant Protection Department, Faculty of Agriculture, Tanta University, Tanta, Egypt. ${ }^{2}$ Central Agricultural Pesticides Laboratory, Agricultural Research Center, Giza, Egypt.

Received: 31 January 2019 Accepted: 25 March 2019

Published online: 03 April 2019

\section{References}

AbdEl-Latief EM, Gindy MAE (2006) Toxicity evaluation of some different pesticides against cotton leafworm Spodoptera littoralis (Boisduval) and aphids Aphis gossypii (Glover) under laboratory conditions. Resist Pest Manage Newsl 20(1):13-16

Ahmad M, Arif Ml, Ahmad Z, Denholm I (2002) Cotton whitefly (Bemisia tabaci) resistance to organophosphate and pyrethroid insecticides in Pakistan. Pest Manag Sci 58(2):203-208

Ali S, Khan M, Sahi S, Hassan M (2010) Evaluation of plant extracts and salicylic acid against Bemisia tabaci and cotton leaf curl virus disease. Pak J Phytopathol 22:98-100

Catinot J, Buchala A, Abou-Mansour E, Métraux JP (2008) Salicylic acid production in response to biotic and abiotic stress depends on isochorismate in Nicotiana benthamiana. FEBS Lett 582:473-478

El-Naggar JB, Zidan NE-HA (2013) Field evaluation of imidacloprid and thiamethoxam against sucking insects and their side effects on soil fauna. J Plant Prot Res 53(4):375-387

Hayat Q, Hayat S, Irfan M, Ahmad A (2010) Effect of exogenous salicylic acid under changing environment: a review. Environ Exp Bot 68:14-25

Johnson G, Schaal LA (1957) Accumulation of phenolic substances and ascorbic acid in potato tuber tissue upon injury and their possible role in disease resistance. Am Potato J 34(7):200-209

Karban R, Kuc J (1999) Resistance against pathogens and herbivores: an overview. In: Inducible plant defenses against pathogens and herbivores. Biochemistry, ecology, and agriculture. American Phyto-pathological Society Press, St. Paul, pp 251-268

Kogan M, Paxton J (1983) Natural inducers of plant resistance to insects. In: Plant resistance to insects. American chemical society, Washington, D. C, pp 153-171

Kunkel BN, Brooks DM (2002) Cross talk between signaling pathways in pathogen defense. Curr Opin Plant Biol 5(4):325-331

Li R, Islam SU, Wu Z, Ye X (2016) Bensulfuron-methyl treatment of soil affects the infestation of whitefly, aphid, and tobacco mosaic virus on Nicotiana tabacum. Front Plant Sci 7(December):1-10

Mahalakshmi R, Eganathan P, Parida AK (2013) Salicylic acid elicitation on production of secondary metabolite by cell cultures of Jatropha curcas L. Int J Pharm Pharm Sci 5(4):655-659

Maswada HF, El-Nagar AS, El-Zahaby HM (2014) Physiological response of squash plants to foliar spray with salicylic acid, nitric oxide, and $\mathrm{H}_{2} \mathrm{O}_{2}$ under biotic stress conditions. J Agric Res Kafrelsheikh Univ 40(4):720-741

Mendhulkar VD, Vakil MMA (2013) Elicitation of flavonoids by salicylic acid and Penicillium expansum in Andrographis paniculata (Burm. f.) Nees. cell culture. Res Biotechnol 4(2):1-9

Robert-Seilaniantz A, Grant M, Jones JDG (2011) Hormone crosstalk in plant disease and defense: more than just jasmonate-salicylate antagonism. Annu Rev Phytopathol 49(1):317-343

Rodríguez-Álvarez Cl, López-Climent MF, Gómez-Cadenas A, Kaloshian I, Nombela $\mathrm{G}$ (2015) Salicylic acid is required for Mi-1-mediated resistance of tomato to whitefly Bemisia tabaci, but not for basal defense to this insect pest. Bull Entomol Res 105(05):574-582

Rodriguez-Saona C, Crafts-Brandner SJ, Cañas LA (2003) Volatile emissions triggered by multiple herbivore damage: beet armyworm and whitefly feeding on cotton plants. J Chem Ecol 29(11):2539-2550

Schepers AA (1989) Their biology, natural enemies and control. In: Chemical control in world crop pests. Elsevier, Amsterdam, pp 89-122

Shi X, Pan H, Xie W, Wu Q, Wang S, Liu Y, Fang Y, Chen G, Gao X, Zhang Y (2013) Plant virus differentially alters the plant's defense response to its closely related vectors. PLoS One 8(12):e83520

Stout MJ, Fidantsef AL, Duffey SS, Bostock RM (1999) Signal interactions in pathogen and insect attack: systemic plant-mediated interactions between pathogens and herbivores of the tomato, Iycopersicon esculentum. Physiol Mol Plant Pathol 54(3-4):115-130

Thaler JS, Agrawal AA, Halitschke R (2010) Salicylate-mediated interactions between pathogens and herbivores. Ecology. 91(4):1075-1082

Ti X, Zhang Q (2009) Advances in research of induced resistance to insects in cotton. Front Biol China 4(3):289-297

VanDoorn A, de Vries M, Kant MR, Schuurink RC (2015) Whiteflies glycosylate salicylic acid and secrete the conjugate via their honeydew. J Chem Ecol 41(1):52-58

Villada ES, Gonzalez EG, Lopez-Sese Al, Castiel AF, Gomez-Guillamon ML (2009) Hypersensitive response to Aphis gossypii Glover in melon genotypes carrying the Vat gene. J Exp Bot 60(11):3269-3277

War AR, Paulraj MG, War MY, Ignacimuthu S (2011) Herbivore- and elicitorinduced resistance in groundnut to Asian armyworm, spodoptera litura(fab.) (lepidoptera: Noctuidae). Plant Signal Behav 6(11):1769-1777

\section{Submit your manuscript to a SpringerOpen ${ }^{\circ}$ journal and benefit from:}

- Convenient online submission

- Rigorous peer review

- Open access: articles freely available online

- High visibility within the field

- Retaining the copyright to your article

Submit your next manuscript at $\boldsymbol{\nabla}$ springeropen.com 